This article is (c) Emerald Group Publishing and permission has been granted for this version to appear here (https://dspace.lib.cranfield.ac.uk/index.jsp). Emerald does not grant permission for this article to be further copied/distributed or hosted elsewhere without the express permission from Emerald Group Publishing Limited.

www.emeraldinsight.com

\title{
A Dynamic Theory of Leadership Development
}

\begin{abstract}
Purpose - The paper offers a dynamic theory of leadership development.

Design/methodology/approach - The paper examines selected leadership literature through the lens of theory building blocks. It identifies the role of the ideal goal in leadership and its importance in developing the psychological aspect of leadership.
\end{abstract}

Findings - The paper posits that leadership is a developmental process, which is based on the type of choice a leader makes. While choice implies that two good options are always available from which to select, one should make choices in accordance with his worldview, looking for affiliation (i.e. the Theta worldview), or looking for achievement (i.e. the Lambda worldview). Consequently, leaders need to recognise that the choices they make for organisational activities have to fit their own worldview. Pursuing the fit between one's worldview and planned organisational activities ensures that leaders continuously improve their ethical behaviour. The paper concludes with the presentation of a dynamic theory of leadership, which is based on the assumption that one can only strive toward truly ethical leadership with the knowledge that this goal is beyond human capacity. 
Research limitations/implications - Being a theory-based exploration, the paper does not provide empirical examples of how this theory might be applied in practice.

Originality/value - The paper provides an example of a dynamic theory, introduces the concept of Theta and Lambda worldviews and provides a better definition of leadership strategy and tactics.

Article type - Conceptual paper

Key words - Dynamic theory, leadership, leadership development, Theta worldview, Lambda worldview, worldview

\section{Introduction}

Scholars tend to hold two mutually exclusive views about leadership: one school of thought holds that leaders are born (Grint, 2000, Nietzsche, 1969) and that the qualities they embody are subconscious (Lowen, 1975) whilst the other posits that humans need to work hard to develop these qualities before they can emerge as leaders (Henrikson, 2006; Kakabadse and Kakabadse, 1999; Kakabadse and Myers, 1996).

The 'great man' theory (Carlyle, 1841/2007; James, 1880) exemplifies the former view and is interested in the personality traits which leaders intrinsically possess (Kakabadse and Kakabadse, 1999). This approach assumes that a 'great man' naturally holds the essential skills which allow him to perform as a leader. By identifying these essential traits, others can emulate them through simulated versions of leadership (Kenny and Zaccaro, 1983; Lawler, 2005; Stogdill, 1948; Stogdill, 1982). When applying this approach, scholars analyse specific tasks or problems and provide leadership typologies for addressing them (Mullins, 2003; Hersey and Blanchard, 1993; Bass and Avolo, 1990). Many scholars have explored the 
behaviour of leaders, the impact of context or 'situation' on leadership (Yukl, 2006), the function of leadership (Shamir, 1995), as well as 'contingency' and dynamic processes (Baker, 2007; Fiedler, 1967). Both the behavioural perspective as well as the economic model examine leadership as a role whose purpose is to assist an organization to adapt. That is how an individual practicing leadership can help an organisation to affect adaptive change (Kotter, 1990; Heifetz, 1998; Nanus, 1995).

The developmental school of thought, on the other hand, seeks to understand the conscious steps taken to become a leader. Rooted in existentialist phenomenology, it holds that human development as well as human history is created (i.e. 'caused') by our awareness of our own mortality (i.e. existential 'time') which shapes everyday lives as a continuous interpretation of experience of the past and expectation (i.e. 'anticipation') of the future (Koselleck, 2002, 1985). In this case, personal life "is a constant becoming through a constant intentionality of development" (MacDonald, 2000, p.33), and human existence is centred on the idea of possibility where "he is always more than he is; his being is never complete at any given moment" (Sartre, 1973, p.32). This view suggests that articulations of one's experience and anticipation of the future are subject to interpretation and evolve over time (Nanus, 1995; MacDonald, 2000). The developmental school holds that leadership is grounded in experience and reflected by the personal interpretation of specific meanings articulated by inconsistent uses of language (Kakabadse and Kakabadse, 1999). These, in turn, influence the development of future perspectives (Alvesson and Svenningson, 2003). Although scholars argue that leaders should exhibit some needed personal qualities (e.g., Goleman, 1998; Kotter, 1990; Zaleznik, 1977), the above list does not offer a comprehensive theory of what leadership entails, especially when these leadership qualities are not found in practice. Moreover, notwithstanding burgeoning academic endeavours in the field of leadership, we still do not know why leadership calls for those qualities. However, our goal is not simply to 
criticise existing views on leadership. Instead, we take leadership to be a process (Baker, 2007) and present here a dynamic theory of leadership which refers to time (Ashforth et al., 2008). This theory will enable us to explain the process of leadership development, explaining that the two opinions concerning leadership transformations are not at odds but complement each other. In addition, we will not only identify the gaps in the existing literature and attempt to fill them, but also assess the relevance of the current literature.

We will develop our argument starting with some basics, first by explaining the theoretical meaning of leadership and its application in practice. Next, we will examine some of the leadership qualities recognised by the literature as a context for arguing that the full embodiment of this list of qualities is beyond human reach. Consequently, we will expand on what leaders do in practice. We will introduce the two mutually exclusive worldviews of leaders, the Theta and the Lambda, from which leaders can choose and the three levels of activity of leadership theory. We will follow this discussion by introducing the concept of ideal leadership and then presenting a dynamic model of leadership theory. Leaders are few and not many are ready to face the challenges expected in this role. We will identify those challenges. Finally, we will explain why leadership theory, which seems to be relevant to only a few of us, is actually meaningful to us all.

\section{The Theory of Leadership}

Adding to Kurt Lewin's (1945) observation that "there is nothing so practical as a good theory," Whetten (2002) suggests that only a good theory is practical. Hence, we have two successive goals: first, we should understand the components that comprise theory and second, we should incorporate this knowledge into the theory of leadership. 
Like any theory, leadership theory has to answer to three key questions: what, why and how (Whetten, 2002). "What" refers to the constructs analysed, or the target of theorising; "how" explains the methods we use to create interrelationships between constructs of the theory; and "why" represents the conceptual assumptions behind these relationships (Figure 1).

Figure 1: The three components of theory

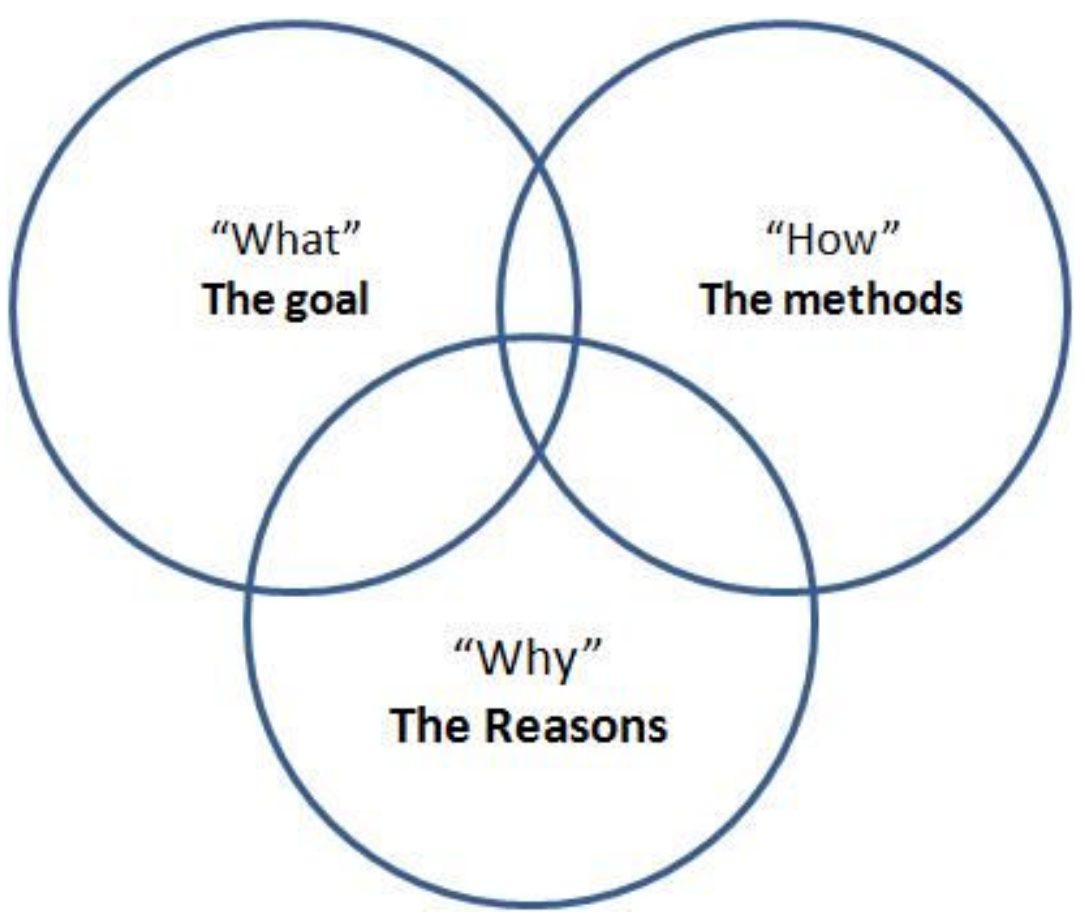

Source: Mostovicz (2008)

Thus, in leadership theory the "what" represents the goal that the leader looks to attain, the "how" explains the way the leader reaches the goal, and the "why" explains the reasons behind selecting this particular method for attaining the goal. However, we contend that while the literature into leadership deals with what leaders do or how they do it, it is silent 
about the reasons for why leaders are motivated to pursue such activities. This paper seeks to address this gap in leadership theory. However, for forwarding our explanation, we will first critically review a selection of the literature into leadership that we will use as a context to our discussion.

\section{The Leadership Timeline}

In general, research into leadership has examined three different phases within the leadership timeline: the past, the present, and the future. Respectively, they represent how leaders have been transformed, their social role, and how they identify and execute their purpose. As Figure 2 shows, the model is in line with Koselleck (2002; 1985), and it defines and captures human development fuelled by the vision of possibilities.

Figure 2: The leader's timeline.

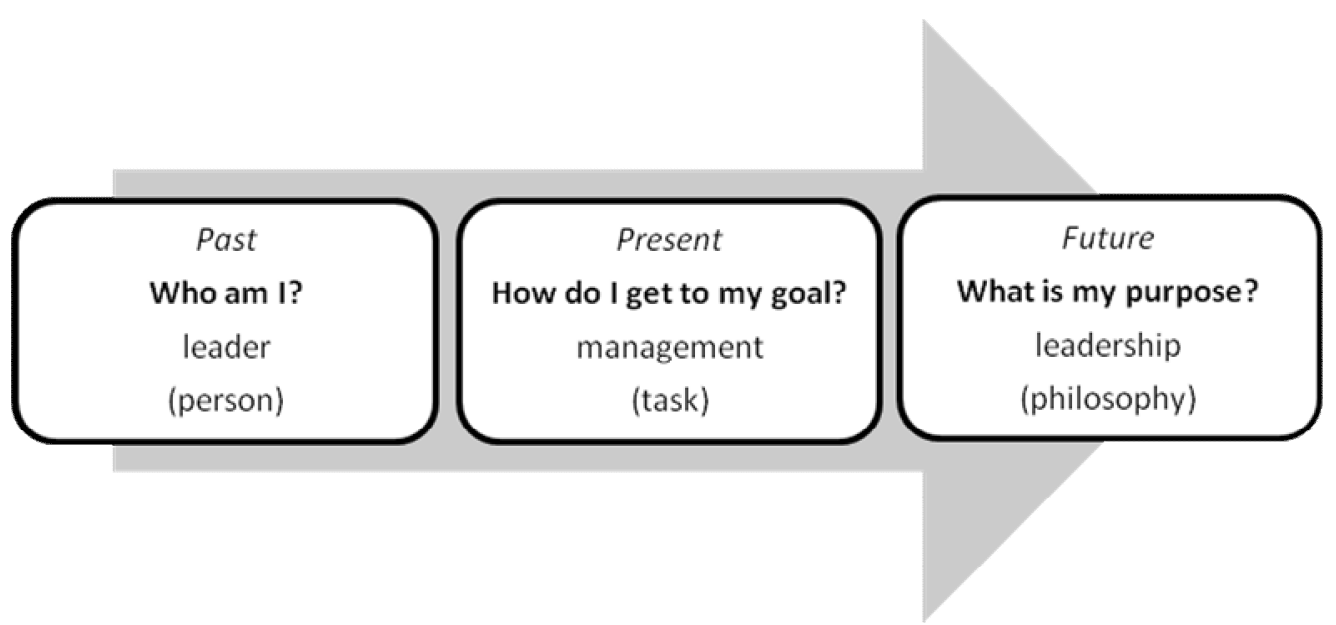

Source: the authors

\section{The past}

Who is the leader or what qualities do ideal leadership require?. One quality of a leader is self-awareness (Goleman, 1998, p.84), which we define as "having a deep understanding of 
one's emotions, strengths, weaknesses, needs, and drives." By this definition, leaders should also understand their own values and goals in order to express themselves accurately and openly. This suggests that good leaders are able to clearly articulate their deepest emotions and life goals, a feat which psychological research suggests people find difficult (Niemeyer, Anderson and Stockton, 2001). Equally, people tend to incorrectly define their perceptions as "truth", which leads to emotional distortion (Mostovicz, Kakabadse and Kakabadse, 2008).

Individuals express a difference in their thinking and actions, as shown in the gap between what they say ("espoused theory") and what they actually do ("theory in use") (Argyris and Schön, 1978). Hence, the "deep understanding of one's emotions" (Goleman, 1998, p. 84) is never deep enough to bridge the gap between his intellectual understanding and his ability to apply this emotional learning, since emotions are embedded in the subconscious. In his uprooting of traditional Western viewpoints on the subject, Freud (1948) concluded that the subconscious determines personal preferences rather than the consciously pursued intellectual efforts. Freud's challenge also laid the foundation for a wider debate within intellectual circles of the psychological origins of personal development (Lesser 1957).

Besides lacking in self-awareness, humans also cannot act responsibly at all times as there will always be some areas or times when we act automatically or hide behind rules and customs (Mostovicz and Kakabadse, 2008). Consequently, we cannot expect leaders who at times are unaware of their actions to act ethically. The inability led some researchers to realise that while true ethics is beyond our perception, we can gain better insight by developing dynamic models of flux (Csikszentmihalyi, 1990). Scholars who view ethics as a process rather than an end ( e.g., Ciulla, 2004a; 2004b; Caldwell et al., 2008; Flynn, 2008; Hernandez, 2008; Liedtka, 2008; Verbos et al., 2007) pay attention to the deep, personally- 
held virtues, which generally relate to flourishing, vital, meaningful life-purposes and their embodiment (Cameron, 2003; Manz et al., 2006; Knights and O'Leary, 2006; Weiner, 1993). Scholars (Luthans and Avolio, 2003; Gardner et al, 2005; Yammarino et al, 2008) who argue for the need to develop authentic leadership, Liedtka (2008), for example, call for a search for authenticity by looking internally (Hernandez, 2008; Hardt, 1993) rather than externally as logical, economics-driven theories of ethics advocate. Lévinas (1994) addresses this question by replacing the concept of authenticity with the idea of responsibility to the "Other" as the ultimate ethical value.

\section{The present}

The present refers to the social environment inside which a leader acts. A trait commonly found in leaders is empathy. Goleman (1988, p. 88) defines empathy as "the ability to understand the emotional makeup of other people" and "the skill of treating people according to their emotional reactions." To empathise means to respect the other's goals and motives. But because leaders are unclear about their own values and purpose, their ability to empathise with those of others is equally constrained.

While Goleman (1988, p. 88) identifies self-regulation, or "the ability to control or redirect disruptive impulses and moods and the propensity to suspend judgment - to think before acting", this supposed self-regulation or the ability to control emotions and think logically is, at best, wishful thinking, since this introjected, non-autonomous self-regulation is inauthentic (Ryan and Brown, 2003) Thus, we not only are unable to control our subconscious but also the impacts that our subconscious has on our actions (Ariely, 2008).

\section{The future}

Humans need a purpose. As each person has his own individual personality, he therefore searches for a unique purpose (Frankl, 1963). This assertion, so basic to Judaism, claims that 
"the foundation of Judaism and the basis of all true religions is the realization that existence is purposeful, and that man has a purpose in life" (Kaplan, 1979 ,p.1), and it is recognised nowadays by cognitive psychologists as well (e.g., Deci and Ryan, 2000; Pinker, 2003). While we cannot attain true purpose, man is aware that he has a purpose and should search for it (Frankl, 1963). Hence, contrary to Mills (2003) who claims that this search for meaning is only a means for dealing with uncertainty, theorists perceive searching for a purpose (e.g., Frank1, 1963; Kelly, 1955; Nonaka and Takeuchi, 1995; Yamakage, 2000) as a goal.

However, people tend to believe in their ability of reaching a purpose out of fear of imperfection (Pinker, 2003), resulting in frustration when they realise that they cannot attain the purpose. This leads to the development of noögenic ${ }^{i}$ neuroses, or what others might call spiritual or existential neuroses (Frankl, 1963). They shed all striving for meaning and live a boring and meaningless life. Another prevailing option is to substitute the unattainable purpose with a reachable one, such as the "American dream" (Adams, 2001), which only delays the neurosis until people reach this attainable but wrong purpose.

Focusing on the search for purpose as a goal requires maturity, one of the most important qualities of a leader (Zaleznik, 1977). Just as marathon runners are usually older than those who run short distances, leaders' applied abilities improve with age because they have stronger mental stamina. Similarly, marathon runners have to struggle with an invisible target that does not become visible for some time. Therefore, they run unconsciously (Frankl, 1975) and concern themselves less with the target and more with their own actions until the target begins to reveal itself. 
Another trait which virtually all leaders have is motivation. Goleman (1998, p. 88) defines motivation as a "passion to work for reasons that go beyond money and status" and "a propensity to pursue a goal with energy and persistence." However, how can leaders "pursue a goal" when their purpose is unclear? Second, self-motivation is an ideal only as in reality, one needs a measure of extrinsic provocation (Gagné and Deci, 2005). As a matter of fact, those who fail to grasp this human inability to pursue a goal end up trying or thinking too hard and develop neuroses as a result (Frankl, 1963; Wilson and Schooler, 1991).

\section{What do leaders do?}

If most of the leadership qualities mentioned above seem not to exist in reality, aspiring leaders may remain unaware of how to progress in their development. Literature has paid less attention to the role of leadership and instead has concentrated more on how leaders are fulfilling that role. Hence, we need to answer three questions: first, what the role of leadership is, second, what the role of nonexistent ideal leadership in practice is and lastly, what the role of all the traits that the literature into leadership identified in developing leaders is.

Leadership is about making choices (Kouzes and Posner, 2003). Choice is a binary action that divides options into two sets, the desired and the undesired ones, according to a higher principle or value (Rawls, 1999). Thus, a choice implies that while both options are equally valid, one will choose according to a higher principle. Mostovicz (2008) posits that the way people choose is a reflection of their worldview or the way they go about discovering their 
“ideal self” (Hinkle, 1965). We approach this discovery in one of two ways: by the need for achievement (the Lambda worldview) or by the need for affiliation (the Theta worldview).

Each worldview has its unique characteristics. While the Thetas' motivation is socially oriented and they look to affiliate with their society of choice (Pyszczynski et al. 2004; Pyszczynski, Greenberg and Solomon, 1997), the Lambdas are individually motivated (Deci and Ryan, 2000). Consequently, their respective behaviour follows the fundamental modalities of human existence (Bakan, 1966). Thetas' behaviour is toward communion and focused on other people and relationships while Lambda's behaviour is toward agency and focused on the self and autonomy. The different approaches seek different benefits. Thetas try to build respect within their society of choice while Lambdas look for personal freedom (Mostovicz, 2008). While scholars argue that leaders should exhibit the personal quality of authenticity (e.g., Goleman, 1998; Kotter, 1990; Zaleznik, 1977), Thetas and Lambdas differ in the way they relate to authenticity. While Thetas are concerned with truthfulness and denounce fakes (Ciulla ,2004; Nanus ,1995; Pyszczynski, Greenberg and Solomon ,1997; Pyszczynski et al. ,2004), Lambdas "are genuine and authentic, not a replica of someone else" (George et al. ,2007, p.129) and perceive authenticity as uniqueness, with negative views of a "me too" practice (Bennis ,2004; Deci and Ryan ,2000; Ryan and Brown ,2003).

Finally, the different worldviews have different ideas about what a true goal is. According to Kaplan (1990), one relates to truth either as an objective or as a principle. If one relates to truth as an objective, the goal is to unite with it, as the Thetas perceive. If, on the other hand, one relates to truth as a principle, as a Lambda does, truth then creates a set of challenges or guidelines to live up to. This difference in perception of truth also explains why different 
opinions exist about how leaders transform (Kakabadse and Kakabadse, 1999). To a Theta, a true leader is one who attained his objective or one who is able to act subconsciously (Lowen, 1975) and naturally - a born leader (Grint, 2000; Nietzsche, 1969) while for a Lambda, a genuine leader is one who follows meticulously a proper set of guidelines (Henrikson, 2006; Kakabadse and Kakabadse, 1999; Kakabadse and Myers, 1996).

These two approaches clash fundamentally because the drive for achievement ends in separating oneself from others (or making oneself unique), while its counterpart seeks to affiliate oneself with others and work in unison. Consequently, this tension can lead to personal bias or a distortion of the paradox within leadership (Mostovicz et al., 2008). A Theta type tends to choose the alternative course of action whereby he dilutes the stakes by substituting a relative truthfulness for the ultimate truth or creates a lack of contrast by removing a strongly desired choice. On the other hand, in the Lambda type, the learning paradox can cause one to lose his own personality and to seek collectivism or even fanaticism in extreme cases whereby one disrespects others' interpretation of truth or argues that it is invalid (McGregor et al. 1998, see Frankl 1986, p.xxvi for a similar idea). Table 1 below outlines several of the characteristics which define these two worldviews and how they approach their practice of leadership.

Table 1: Leadership Characteristics of Theta ( $\square$ and Lambda ( $\square$ ) worldviews

\begin{tabular}{|l|l|l|}
\hline & Theta $(\square$ & Lambda ( $\square$ \\
\hline Motivation/reason & Socially oriented & Personally oriented \\
\hline Goal & Seeking unity and certainty & Seeking challenge and \\
& & creation \\
\hline
\end{tabular}




\begin{tabular}{|l|l|l|}
\hline Behaviour & Communion & Agency \\
\hline Benefit & Building respect & $\begin{array}{l}\text { Looking for personal } \\
\text { freedom }\end{array}$ \\
\hline Principle & Authenticity = truthfulness & Authenticity = genuineness \\
\hline Inclination & Toward choice & Toward contrast \\
\hline Perception of truth & As an objective & As a set of rules \\
\hline $\begin{array}{l}\text { Transformation of } \\
\text { a leader }\end{array}$ & $\begin{array}{l}\text { A leader is born. Qualities } \\
\text { are subconscious. }\end{array}$ & $\begin{array}{l}\text { A leader is developed } \\
\text { consciously. }\end{array}$ \\
\hline
\end{tabular}

\section{Source: the authors}

Incorporating both approaches is paradoxical because this requires one to relate to the other despite being motivated in a different way (Mostovicz et al., 2008). This paradox creates an ethical problem because it implies that the leader is supposed to view a clashing code of conduct as both a proper and a good conduct yet also as unethical. Moreover, it begs the question of how one can perceive two opposing conducts as equally ethical.

Hence, leadership consists of three levels (Table 2). The lower level consists of the many tactics or actions (Amir and Ariely, 2007) that are based on the Theta/Lambda principles. As such, these actions are logical, rational, conscious, measurable and replicable, and their guiding discipline is economics. Strategy is a matter of interpretation and often involves the making of choices (Porter 1996), which are themselves paradoxical (Mostovicz et al., 2008). This is the level of practical leadership that we characterise as emotional, unconscious, irrational and immeasurable and whose guiding discipline is psychology. However, this level 
is properly performed only when it is embedded in true purpose and its leading discipline is of metaphysics. While man cannot perceive truth, he is able to progress toward it. Nevertheless, he has to progress naturally and faithfully according to his worldview, which can be of a Theta or a Lambda type.

Table 2: The Three Components of Leadership Theory

\begin{tabular}{|l|l|l|l|}
\hline Theory question & How? & What? & Why? \\
\hline $\begin{array}{l}\text { Organisational } \\
\text { component }\end{array}$ & Tactics & Strategy & Leadership \\
\hline Leading discipline & Economics & Psychology & Metaphysics \\
\hline Type of Action & $\begin{array}{l}\text { Logical, measurable } \\
\text { and replicable. } \\
\text { Conscious }\end{array}$ & $\begin{array}{l}\text { Emotional, a matter } \\
\text { of choice. } \\
\text { Subconscious }\end{array}$ & Does not exist \\
\hline
\end{tabular}

Source: the authors

\section{The Dynamic Theory of Leadership Development}

Recently, scholars have criticised theories in social science for being static (Ashforth et al. 2008) or for not taking into account the element of time. Theories that scholars considered correct in the past have become invalid over time (Pascale, 1990; Kalogeras, 2005). Consequently, social science, in general, and the process of leadership (Baker, 2007), in particular, are looking for dynamic theories.

Ideal leadership and ethics share one thing in common, neither the former nor the latter is to be found in man. Nevertheless, as such, they present an ideal for anchoring leadership theory. 
Weber (1947) and Hekman (1983) use the term "ideal" only as an aid to assist in explaining patterns of social interaction, institutional design and the way we govern ourselves (Cutting and Kouzmin, 2000). Hence, "ideal" does not try to describe a particular behaviour but looks to capture the logic of reality we use meaningfully as an inspirational benchmark. We expand beyond this normative approach and view the ideal type or the ethical leader as a particular entity and argue that this ideal is not a passive and static benchmark for measuring our success, but an active and dynamic part of the leadership theory. Unable to reach the ideal, the pursuit of ideal leadership is guaranteed to fail, yet it assures the dynamic and successful development of the leader.

While the metaphysical ideal serves as an anchor for guaranteeing a leader's dynamic development, a leader gets closer to that ideal either by following the Theta or the Lambda pattern according to his worldview. Nevertheless, we must express this worldview in tactical actions that fit (Porter, 1996) the particular worldview (Figure 3). However, as we will explain, tactics have a dual role. Not only do we use them as a means of expression of the leader's strategy, but as a mirror that reflects the bitter truth to the leader, telling him what he is not doing properly. 
Figure 3: The Dynamic Theory of Leadership Development

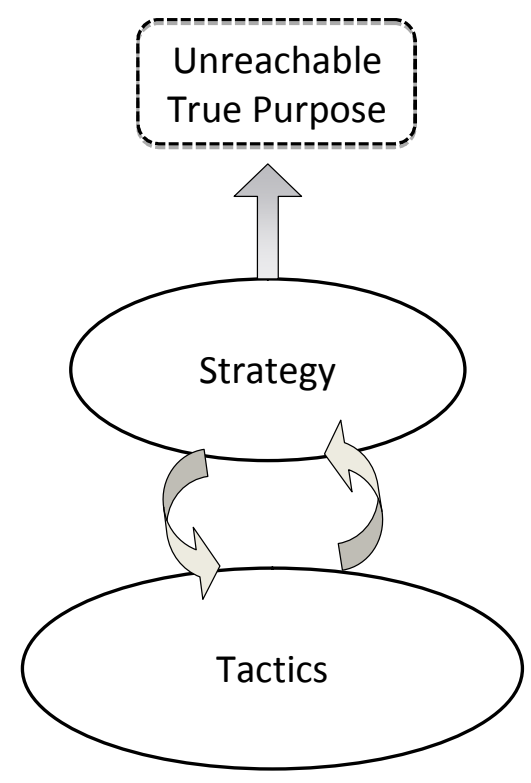

Source: the authors

We believe that the selection of our tactical goals is based on logic. Nevertheless, Porter (1996) reminds us that we should not account for all actions since these actions should fit our strategic view. According to this approach, the tactical goals are the independent variables that dictate to us what to do while the strategic view helps us to select those goals more suitable to our capabilities. Inherently, this approach suffers from what might be called "objectivity fallacy" or the belief that we are able to collect data or define tactical goals objectively. However, we select subjectively only the data that fits our worldview (Mostovicz, 2008; Mostovicz, Kakabadse and kakabadse, 2008). Thus, the tactical activities are dependent variables only. Hence, leadership development starts with clarifying the 
emotional, strategic worldview first before defining those tactical methods that can enhance the strategy.

\section{The leadership challenge}

Why are there so few leaders? In Kakabadse and Kakabadse's (2007) study, only a handful of people in leadership positions actually led while the vast majority acted reactively, either seeing their role as pleasing the shareholders or being concerned with their reputation. Not only were there not enough leaders to fill existing leadership slots in management, but the gaps are even greater as some leaders decline to practice their leadership in the field of business management (Goffee and Jones, 2000). The result is that filling these leadership roles is a huge challenge.

Leadership calls for total commitment to the perpetual process of purpose seeking. While leaders are usually concerned with their legacies, their commitment to purpose has to go far deeper. It is not simply how a leader has lived his life but how he has defined a purpose for which he would have been ready to die if it could not have been pursued (Lévinas 1994). This total commitment implies that, in reality, leaders seek 'either my way or nothing.' However, this commitment is intrinsic; it calls for the leader to mobilise himself, body and soul, but in no way does it imply extrinsically that what is not "my way" is wrong.

This total commitment is not easy. The only tool left at the leader's disposal is motivation, which implies flux. A leader should be constantly on the move, trying to achieve the unachievable and relating to what looks like a means as a life goal. However, as this 
motivation is always extrinsically triggered (Gagné and Deci, 2005), it does not happen regularly, and a good leader should seek that extrinsic motivation constantly and even provoke it (Nonaka and Takeuchi, 1995).

A leader faces a challenge at the strategic level as well. It is not enough to pursue a goal and a leader has to follow it strictly according to his worldview while respecting the other's worldview. This respect of the other is empathy or what Lorenz (1974) calls a bond associated with being both non-hierarchical and non-distancing. When leaders bond socially, they need to send a message that humans all share a common existence and a lack of selfawareness of the ethics required to search for a true purpose. While establishing empathy is a momentary act based on a complex unconscious process (Wilson, 2002), leaders are aware of this but try to unmask it or try to be more aware of themselves.

Empathy requires three qualities: avoidance of distancing, respect for the integrity of the other and harmonious aggression (Ohshima, 1998). We can only achieve harmony by setting boundaries around the aggressive act while signalling respect for the adversary's integrity (Funakoshi, 1973). This ability to manage a spectrum of aggression may not be unique to humans. As Lorenz (1974) has pointed out, members of a given animal species also find it important to keep their aggression intact and to learn to avoid potentially dangerous repercussions by means of diverting mechanisms.

However, proper empathy or being ethical is trying to hold the stick at both ends and tends to lead to paradoxical distortion (Mostovicz et al., 2008) that the leader needs to fight 
constantly. Empathy is the reconciliation between the closeness of responsibility and the distancing as defined by the Other (Lévinas, 1994). We can only strive to reach this ideal but we will never attain it.

Finally, the tactical level has its challenges as well. While an organisation has one leader only to dictate its future direction, many fall into the trap of transactional leadership where they base their leadership on formal authority (Kakabadse and Kakabadse, 1999). Such behaviour is based on the logic of self-regulation while leadership should be based on a voluntary emotional concession of any competing goals by others in the organisation (Murnighan and Conlon, 1991). Thus, instead of mistakenly marginalising individual experience in the search for overall homogeneity, a leader should learn to "play through" (Murnighan and Conlon, 1991) any differences that individuals may have so that he does not deny "the right of individual people to have and interpret their own experience" (Cheng, 1995 ,p.5).

\section{Conclusion}

Ideal leaders do not exist in practice. Thus, we can relate to leadership as a progressive development only. Since humans cannot be fully conscious of our emotions, a posteriori, we cannot fully mobilise them in order to understand and attain our life goals and purpose. Because our purpose remains opaque at best, it follows that leaders will act unethically even when they do so unwillingly or unconsciously. The only way for leaders to improve their ethical position is to interact with others in society to help them reveal their hidden agenda over time. The particular worldview, in turn, shapes these agendas, either Theta or Lambda, 
that a person embodies in his search for greater self-awareness and contextualisation with his external environment.

\section{References}

Adams, J.T. (2001), The Epic of America, Simon Publications, Phoenix, AZ.

Alvesson, M. \& Svenningson, S. (2003), "Managers Doing Leadership: The ExtraOrdinarization of the Mundane", Human Relations, Vol. 56, No. 12, pp. 1435-1459.

Amir, O. \& Ariely, D. (2007), "Decisions by Rules: The Case of Unwillingness to Pay for Beneficial Delays", Journal of Marketing Research, Vol. 44, No. 1, pp. 142-152.

Argyris, C. \& Schön, D.A. (1978), Organisational Learning, Addison-Wesley, Reading.

Ariely, D. (2008), Predictably Irrational: The Hidden Forces that Shape our Decisions, HarperCollins, New York.

Ashforth, B.E., Gioia, D.A., Robisnson, S.L. \& Trevino, L.K. (2008), "Re-Viewing Organisational Corruption", Academy of Management Review, Vol. 33, No. 3, pp. 670684.

Bakan, D. (1966), The Duality of Human Existence: Isolation and Communion in Western Man, Rand McNally, Chicago.

Baker, S.D. (2007), "Followership: The Theoretical Foundation of a Contemporary Construct", Journal of Leadership and Organizational Studies, Vol. 14, No. 1, pp. 50-60.

Bass, B.M. \& Avolio, B.J. (1990), Multifactor Leadership Questionnaire, Consulting Psychologists Press, Palo Alto, CA.

Bennis, W. (2004), "The Crucibles of Authentic Leadership" in The Nature of Leadership., Antonakis, J., Cianciolo, A.T. \& Sternberg, R.J. (Eds.), Sage Publications, Thousand Oak, CA, pp. 331-342.

Caldwell, C., Hayes, L.A., Bernal, P. \& Karri, R. (2008), "Ethical Stewardship - Implications for Leadership and Trust", Journal of Business Ethics, Vol. 78, No. 1-2, pp. 153-164.

Cameron, K.S. (2003), "Organizational Virtuousness and Performance" in Positive Organizational Scholarship: Foundation of a New Discipline, eds. K.S. Cameron, J.E. Dutton \& R.E. Quinn, Berrett-Koehler, San Francisico, CA. 
Carlyle, T. (1841/2007), On Heroes and Hero Worship and the Heroic in History, Kessinger, Whitefish, MT.

Cheng, C.(1995), "Experience, Essentialism and Essence: Changing Organizations through Personal Work and Gender Stories", Journal of Organisational Change Management, Vol. 6, No. 6, pp. 3-7.

Ciulla, J.B.(2004a), "Leadership Ethics: Mapping the Territory" in Ciulla, J.B. (Eds.) Ethics: The Heart of Leadership, (2 ${ }^{\text {nd }}$ ed.),Preager, Westport, CT, pp. 3-26.

Ciulla, J.B. (2004b), "Ethics and Leadership Effectiveness." The Nature of Leadership' in Antonakis, J. Cianciolo, A.T. \& Sternberg, R. J. (Eds.), Sage, Thousand Oak, CA, pp.302-327

Csikszentmihalyi, M. (1990), Flux: The Psychology of Optimal Experience, HarperCollins, New York.

Cutting, B. \& Kouzmin, A. (2000), "The Emerging Patterns of Power in Corporate Governance - Back to the Future in Improving Corporate Decision Making", Journal of Managerial Psychology, Vol. 15, No. 5, pp. 477-507.

Deci, E.L. \& Ryan, R.M. (2000), "The "what" and "Why" of Goal Pursuit: Human Needs and Self-Determination of Behavior", Psychological Inquiry, Vol. 11, No. 4, pp. 227-268.

Fiedler, F.E. (1967), Theory of Leadership Effectiveness, McGraw-Hill Education, New York.

Flynn, G. (2008), "The Virtuous Manager: A Vision for Leadership in Business", Journal of Business Ethics, Vol. 78, No. 3, pp. 359-372.

Frankl, V.E. (1986), The Doctor and the Soul, Vintage Books, New York.

Frankl, V.E. (1975), The Unconscious God: Psychotherapy and Theology, Simon \& Schuster, New York.

Frankl, V.E. (1963), Man's Search for Meaning: An Introduction to Logotherapy, Washington Square Press, New York.

Freud, S. (1948), "One of the Difficulties of Psycho-Analysis (1917)" in Collected Papers, ed. S. Freud, Hogarth Press, London, pp. 347-556.

Funakoshi, G. (1973), Karate do Kyohan, Kodansha, Tokyo. 
Gagné, M. \& Deci, E.L. (2005), "Self-Determination Theory and Work Motivation", Journal of Organizational Behavior, Vol. 26, No. 4, pp. 331-362.

Gardner, W. L., Avolio, B. J., Luthans, F., May, D. R., \& Walumbwa, F. (2005), "Can You See the Real Me?" A Self-Based Model of Authentic Leader and Follower Development. Leadership Quarterly, Vol 16, No.3, pp. 343-372.

George, B., Sims, P., McLean, A. \& Mayer, D. (2007), "Discovering Your Authentic Leadership", Harvard Business Review, Vol. 85, No. 2, pp. 129-138.

Goffee, R. \& Jones, G. (2000), "Why should Anyone be Led by You?", Harvard Business Review, Vol. 78, No. 5, pp. 62-70.

Goleman, D. (1998), "What Makes a Leader?", Harvard Business Review, Vol. 76, No. 6, pp. 93-102.

Grint, K. (2000), The Arts of Leadership, Oxford University Press, Oxford.

Hardt, H. (1993), "Authenticity, Communication and Critical Theory", Critical Studies in Mass Communication, Vol. 10, No. 1, pp. 49-69.

Heifetz, R. A. (1998), Leadership without Easy Answers, Harvard University Press, Cambridge, MA.

Hekman, S.J. (1983), Weber, the Ideal Type and Contemporary Social Theory, University of Notre Dame, Notre Dame.

Henrikson, M. (2006), "Great Leaders are made, Not Born: Conclusion of a Four-Part Series", AWHONN Lifelines, Vol. 10, No. 6, pp. 510-515.

Hernandez, M. (2008), "Promoting Stewardship Behavior in Organizations: A Leadership Model", Journal of Business Ethics, Vol. 80, No. 1, pp. 121-128.

Hersey, P. \& Blanchard, K.H. (1993), Management of Organizational Behaviour; Utilising Human Resources, Prentice Hall., Englewood Cliffs, NJ.

Hinkle, D. (1965), The Change of Personal Constructs from the Point of View of a Theory of Construct Implication, Ohio State University.

James, W. (1880), "Great Men and their Environment", Atlantic Monthly, Vol. 46, No. 276, pp. 441-459.

Kakabadse, A.P. \& Kakabadse, N. (2007), Leading the Board, Palgrave edn, London. 
Kakabadse, A.P. \& Kakabadse, N. (1999), Essence of Leadership, International Thomson, London.

Kakabadse, A.P. \& Myers, A. (1996), "Boardroom Skills for Europe", European Management Journal, Vol. 14, No. 2, pp. 189-200.

Kalogeras, C. (2005), "The Invalid Constant Dividend Growth Model”, Proceedings of the Annual Conference of the Association for Global Business, pp. 104-107

Kaplan, A. (1990), Encounters, Maznaim Publishing Company, New York.

Kaplan, A. (1979), The Handbook of Jewish Thought, Vol. 1, Maznaim Publishing Company, New York.

Kelly, G. (1955), The Psychology of Personal Constructs, Norton, New York.

Knights, D. \& O'Leary, M. (2006), "Leadership, Ethics and Responsibility to the Other", Journal of Business Ethics, Vol. 67, No. 2, pp. 125-137.

Koselleck, R. (2002), The Practice of Conceptual History: Timing History, Spacing Concepts, Stanford University Press, Stanford, CA.

Koselleck, R. (1985), Futures Past: On the Semantics of Historical Time, MIT Press, Cambridge, MA.

Kotter, J.P. (1990), "What Leaders really do", Harvard Business Review, Vol. 68, No. 3, pp. 103-111.

Kouzes, J. \& Posner, B. (2003), Leadership Challenge, the, 3rd edn, Wiley, San Francisco, CA.

Lawler, J. (2005), "The Essence of Leadership? Existentialism and Leadership", Leadership, Vol. 1, No. 2, pp. 215-231.

Lesser, S. (1957), Fiction and the Unconscious, Beacon Press, Boston.

Lévinas, E., (1994), Nine Talmudic Readings, Indiana University Press, Bloomington.

Lewin, K.: (1945), "The Research Center for Group Dynamics at Massachusetts Institute of Technology", Sociometry, Vol. 8, pp. 126-135.

Liedtka, J. (2008), "Strategy Making and the Search for Authenticity", Journal of Business Ethics, Vol. 80, No. 2, pp. 237-248.

Lorenz, K. (1974), On Agression, Harverst Books, Orlando, FL. 
Lowen, A. (1975), Biogenetics, Penguin, New York.

Luthans, F. \& Avolio, B. J. (2003), Authentic leadership development. In K.S. Cameron, J. E. Dutton \& R. E. Quinn (Eds.), Positive organizational scholarship: Foundations of a new discipline, Berrett-Koehler, San Francisco, CA. pp 241-258.

MacDonald, P.S. (ed) 2000, The Existential Reader, Edinburgh University Press, Edinburgh.

Manz, C.C., Cameron, K.S., Marx, K.P. \& Manz, K.P. (2006), "A Special Issue: Values and Virtues in Organizations", Journal of Management Spirituality and Religion, Vol. 3, No. $1-2$, pp. 1-12.

McGregor, H., Leiberman, J., Greenberg, J., Solomon, S., Arndt, J., Simon, L. \& Pyszczynski, T. (1998), "Terror Management and Aggression: Evidence that Mortality Salience Promotes Aggression Against Worldview Threatening Individuals", Journal of Personality and Social Psychology, Vol. 74, pp. 590-605.

Mills, J.H. (2003), Making Sense of Organisational Change, Ruthledge, London.

Mostovicz, E.I. (2008), Understanding of Consumers' Needs for Luxury: The Mechanism of Interpretation and its Role in Knowledge Creation, Unpublished doctoral dissertation, University of Northampton, UK.

Mostovicz, E.I. \& Kakabadse, N.K. (2008), "Debunking the Relationship Marketing Myth: Towards a Purposeful Relationship-Building Model?", 5th International Conference for Consumer Behaviour and Retailing Research (School of Business, University of Nicosia, Nicosia, Cyprus, 26th - 29th March).

Mostovicz, I., Kakabadse, N. \& Kakabadse, A.P. (2008), "Janusian Mapping: A Mechanism of Interpretation", Systematic Practice and Action Research, Vol. 21, No. 3, pp. 211-225.

Mullins, L.J. (2003), Management and Organisational Behaviour, FT Prentice Hall, London.

Murnighan, J.K. \& Conlon, D.E. (1991), "The Dynamics of Intense Work Groups: A Study of British String Quartets", Administrative Science Quarterly, Vol. 36, No. 2, pp. 165-186.

Nanus, B. (1995), Visionary leadership, Jossey-Bass, San Francisco, CA

Niemeyer, R.A., Anderson, A. \& Stockton, L. (2001), "Snakes Versus Ladders: A Validation of Laddering Technique as a Measure of Hierarchical Structure", Journal of Constructivist Psychology, Vol. 14, No. 2, pp. 85-105.

Nietzsche, F. (1969), The Will to Power, Vintage, New York. 
Nonaka, I. \& Takeuchi, H. (1995), The Knowledge-Creating Company, Oxford University Press, Oxford.

Ohshima, T. (1998), Notes on Training, Pine Winds Press, Ravensdale, WA.

Pascale, R.T. (1990), Managing on the Edge: Companies That Use Conflict to Stay Ahead, Simon and Schuster, New York.

Pinker, S. (2003), The Blank Slate: The Modern Denial of Human Nature, Penguin, London.

Porter, M.E. (1996), "What is Strategy?", Harvard Business Review, Vol. 74, No. 6, pp. 6178.

Pyszczynski, T., Greenberg, J. \& Solomon, S. (1997), "Why do we Need what we Need? A Terror Management Perspective on the Roots of Human Social Motivation", Psychological Inquiry, Vol. 8, No. 1, pp. 1-20.

Pyszczynski, T., Greenberg, J., Solomon, S., Ardnt, J. \& Schimel, J. (2004), "Why do People Need Self-Esteem? A Theoretical and Empirical Review", Psychological Bulletin, Vol. 130, No. 3, pp. 435-468.

Rawls, J. (1999), A Theory of Justice, revised edition edn, Belknap Press, Cambridge, MA.

Ryan, R.M. \& Brown, K.W. (2003), "Why we Don't Need Self-Esteem: On Fundamental Needs, Contingent Love, and Mindfulness: Comment", Psychological Inquiry, Vol. 14, No. 1, pp. 71-76.

Sartre, J.P. (1973), Being and Nothingness: A Phenomenological Essay on Ontology, Simon \& Schuster, New York.

Shamir, B. (1995), "Social Distance and Charisma: Theoretical Notes and Exploratory Study", Leadership Quarterly, Vol. 6, No. 1, pp. 19-47.

Verbos, A.K., Gerard, J.A., Forshey, P.R., Harding, C.S. \& Miller, J.S. (2007), "The Positive Ethical Organization: Enacting a Living Code of Ethics and Ethical Organizational Identity", Journal of Business Ethics, Vol. 76, No. 1, pp. 17-33.

Weber, M. (1947), The Theory of Social and Economic Organization, Oxford university Press, London.

Weiner, N.O. (1993), The Harmony of the Soul: Mental Health and Moral Virtue Reconsidered, SUNY Press, Albany, NY. 
Whetten, D.H. (2002), "Modelling as Theorizing a Systematic Methodology for Theory Development" in Essential Skills for Management Research, ed. D. Partington, Sage, London, pp. 45-71.

Wilson, T.D. (2002), Strangers to Ourselves: Discovering the Adaptive Unconscious, The Belknap Press of Harvard University Press, Cambridge, MA.

Wilson, T.D. \& Schooler, J.W. (1991), "Thinking Too Much: Introspection can Reduce the Quality of Preferences and Decisions", Journal of Personality and Social Psychology, Vol. 60, No. 2, pp. 181-192.

Yamakage, M. (2000), The Essence of Shinto: Japan's Spiritual Heart, Kodansha, Tokyo.

Yammarino, F. J., Dionne, S. D., Schriesheim, C. A., \& Dansereau. (2008), Authentic Leadership and Positive Organizational Behaviour: A Meso, Multi-Level Perspective. Leadership Quarterly, Vol 19, No.6, pp.693-707.

Yukl, G. (2006), Leadership in Organizations, Prentice Hall, Englewood Cliffs, NJ.

Zaleznik, A. (1977), "Managers and Leaders: Are they Different?", Harvard Business Review, Vol. 55, No. 3, pp. 67-78.

\section{Notes}

'Noös is Greek for mind or spirit 